Agrovoc descriptors: steinernema feltiae; heterorhabditis; thripidae; thysanoptera; efficiency; mortality; thrips (genus); larvae; environmental factors

Agris category codes: $\mathrm{H} 10$

University of Ljubljana

Biotechnical Faculty

Department of Agronomy

COBISS Code 1.01

\title{
First results concerning the efficacy of entomopathogenic nematodes against Hercinothrips femoralis (Reuter)
}

\author{
Stanislav TRDAN ${ }^{1}$, Luka KUŽNIK ${ }^{2}$, Matej VIDRIH ${ }^{3}$ \\ Received March 08, 2007, accepted June 20, 2007. \\ Delo je prispelo 8. marca 2007, sprejeto 20. junija 2007.
}

\begin{abstract}
The efficacy of the entomopathogenic nematodes Steinernema feltiae and Heterorhabditis bacteriophora against larvae and adults of banded greenhouse thrips, Hercinothrips femoralis, was studied under laboratory conditions. The activity of the biological agents under study was determined at three different temperatures $\left(15,20\right.$, and $\left.25^{\circ} \mathrm{C}\right)$, with concentration of 200 infective juveniles per individual (larva or adult), a day:night ratio of 4:20 and relative humidity of $95 \%$. The experiment was conducted in plastic rearing vessels on French bean leaves with a slightly modified version of a method used for studying the bionomics of thrips. The mortality rate of the thrips was determined four days after the application of the nematode suspension. Temperature had significant influence on adult pest mortality, but no significant effects were found with nematode species. Neither temperature nor nematode species had significant effect on larval mortality, which ranged from $23 \%$ (S. feltiae at $25^{\circ} \mathrm{C}$ ) to approximately $50 \%\left(H\right.$. bacteriophora at 15 and $\left.25^{\circ} \mathrm{C}\right)$. Mortality of adults was significantly influenced only by temperature, with the nematodes being most efficient at $25^{\circ} \mathrm{C}$ (approximately $30 \%$ mortality by $H$. bateriophora). The results of our research showed that foliar application of entomopathogenic nematodes might be a relatively efficient way for controlling $\mathrm{H}$. femoralis, but the optimization of environmental factors would likely improve their efficacy further.
\end{abstract}

Key words: Thysanoptera, Terebrantia, Thripidae, Panchaetothripinae, Steinernema feltiae, Heterorhabditis bacteriophora, efficacy

1 Assist. Prof., Ph. D., Jamnikarjeva 101, SI-1111 Ljubljana, P.O. Box 2995, e-mail: stanislav.trdan@bf.uni-lj.si

2 B. Sc., Matije Tomca 1, SI-1230 Domžale

3 Teach. Assist., Ph. D., Jamnikarjeva 101, SI-1111 Ljubljana, P.O. Box 2995 


\section{IZVLEČEK}

\section{PRVI REZULTATI UČINKOVITOSTI ENTOMOPATOGENIH OGORČIC ZA ZATIRANJE RESARJA Hercinothrips femoralis (Reuter)}

V laboratorijskih razmerah smo preučevali učinkovitost entomopatogenih ogorčic Steinernema feltiae in Heterorhabditis bacteriophora za zatiranje ličink in odraslih osebkov resarja Hercinothrips femoralis. Delovanje ogorčic na žuželko smo ugotavljali pri treh različnih temperaturah $\left(15,20\right.$ in $\left.25^{\circ} \mathrm{C}\right)$, koncentraciji 200 infektivnih ličink/osebek, razmerjem med svetlobo in temo $4: 20$ in $95 \%$ relativni zračni vlagi. Poskus smo izvajali v plastičnih gojitvenih posodicah na fižolovih listih, z rahlo modificirano metodo, ki je bila primarno razvita za raziskave bionomije resarjev. Štiri dni po aplikaciji suspenzije ogorčic smo ugotavljali smrtnost izpostavljenih resarjev. Med vrstama ogorčic nismo ugotovili signifikantnih razlik v delovanju na škodljivca. Vrsta ogorčic in temperatura nista imeli signifikantnega vpliva na smrtnost ličink, ki je znašala od $23 \%$ (S. feltiae pri $25^{\circ} \mathrm{C}$ ) do približno $50 \%$ ( $H$. bacteriophora pri 15 in $25^{\circ} \mathrm{C}$ ). Smrtnost odraslih osebkov je bila signifikantno determinirana le $\mathrm{s}$ temperaturo, pri čemer so bile ogorčice najbolj učinkovite pri $25^{\circ} \mathrm{C}$ (približno $30 \%$ smrtnost pri $H$. bacteriophora). Rezultati naše raziskave kažejo, da je lahko foliarna aplikacija preučevanih biotičnih agensov relativno učinkovit način zatiranja resarja $H$. femoralis, z optimiziranjem okoljskih dejavnikov pa je mogoče njihovo učinkovitost še izboljšati.

Ključne besede: Thysanoptera, Terebrantia, Thripidae, Panchaetothripinae, Steinernema feltiae, Heterorhabditis bacteriophora, učinkovitost

\section{INTRODUCTION}

Banded greenhouse thrips, Hercinothrips femoralis (Reuter) (Thysanoptera: Thripidae), belong to a group of some ten Thysanoptera species which have been proven to be noxious to both cultivated and indigenous plants. Thrips are found across Africa, Central and North America and in Europe (Palmer et al., 1989; Simon, 1993). On the Old Continent and in other areas with moderate climate, these pests are particularly noted in greenhouses (Lacasa in Martinez, 1988; Tusnadi in Nemstothy, 1992; Vierbergen, 1995; Reiderne et al., 1997; Pintureau et al., 1999; Nedstam, 2001; Trdan, 2002).

Although $H$. femoralis is known under the common name of sugar beet thrips, it is found almost everywhere where bananas are grown (Lewis, 1997) and also causes economically important damage to a variety of ornamental plants. In fact, it can feed on more than 50 host plants including representatives of the genera Amaryllis, Aralia, Begonia, Chrysanthemum, Croton, Dieffenbachia, Dracaena, Ficus, Gardenia, Hydrangea, Philodendron, Schefflera, Schlumbergera and others (Beshear, 1979; Oetting and Beshear, 1980; Nedstam, 2001). The sucking of the larvae and adults results in the appearance of silver spots and the aesthetic appearances of the attacked plants are further diminished due to the presence of black excrement.

Rare literature sources which deal with the chemical control of $H$. femoralis (Scarpelli and Bosio, 1999) show that these thrips are not tolerant to insecticides. Thus it is possible to use insecticides to reduce the number of the pest quickly and efficiently before they can spread to a greater extent. Recently, however, more and more importance has been assigned to finding environmentally acceptable ways of controlling plant pests (including thrips) - and a major line of research is the use of their natural enemies. Among these natural enemies are the entomopathogenic 
nematodes (EPNs); soil organisms which are mutually associated with bacteria of the family Enterobacteriaceae. The nematodes enter the prey through their body openings. After infection, the EPNs' symbiotic bacteria are released into the insect hemocoel, causing septicemia and death of the insect (Kaya and Gaugler, 1993).

Most previous research employing EPNs has been directed against soil pests (Kaya et al., 2006). Yet increasing research utilizes their application more broadly and in some cases, EPNs have already been used practically. One of these productive lines of research is the foliar application of EPNs with which a faster activity of nematodes can be attained. Amongst the Thysanoptera species, most previous research has been focussed on western flower thrips (Frankliniella occidentalis [Pergande]) (Arthurs and Heinz, 2006; Shapiro-Ilan et al., 2006), which is one of the four most harmful thrips species in the world (Kirk and Terry, 2003).

The aim of our research was to determine the efficacy of EPNs Steinernema feltiae and Heterorhabditis bacteriophora against the larvae and adults of $H$. femoralis. Differences in efficacy were expected between the temperatures and nematode species. Additionaly, we also expected differences in susceptibility of thrips according to their developmental stages.

MATERIAL AND METHODS

\subsection{Entomopathogenic nematodes and banded greenhouse thrips}

A laboratory investigation was carried out in the Entomological Laboratory of the Chair of Entomology and Phytopathology (University of Ljubljana, Biotechnical Faculty, Department of Agronomy) in Ljubljana, Slovenia. Commercial biopreparations of Steinernema feltiae (Filipjev) (Rhabditida: Steinernematidae) and Heterorhabditis bacteriophora Poinar (Rhabditida: Heterorhabditidae) from Koppert B. V. (Berkel en Rodenrijs, The Netherlands) were used in the work. Both biopreparations, which were sent by air-mail, were used within 2 months of their receipt.

Hercinothrips femoralis was reared in the insectarium at room temperature and without artificial light. They were reared on young plants of Mirabilis jalapa and on the leaves of French bean (Phaseolus vulgaris L.). The suitability of the latter plant for rearing this thrips species has already been demonstrated (Takrony, 1973), but the rearing of the thrips on both hosts was relatively simple compared to the older rearing method of this insect (Laughlin, 1971). On both hosts, thrips had more numerous progeny than on a previous tested composition of Chlorophytum comosum and the orchids Oncidium Gower Ramsey and Epidendrum 'Ballerina yellow'. Adults and larvae of the pest were used for the laboratory research.

\section{$2.2 \quad$ Laboratory bioassay}

Suspensions of EPNs were prepared in glass jars. The efficacy of agents was tested using a concentration of 200 infective juveniles (IJs) per individual (larva or adult) or $1000 \mathrm{IJs}$ in $1 \mathrm{ml}$ of water. Transparent plastic vessels $(10 \times 10 \times 3.5 \mathrm{~cm})$ were used for the rearing of thrips. This rearing method has been used before to study the bionomics of thrips (Trdan, 2000). In contrast to the original method, no pollen was added to the bean leaves in the present study. Five thrips adults (or larvae) were transferred onto each leaf using a fine-tip brush. Following this, $1 \mathrm{ml}$ of nematode suspension was added to each leaf, whereas in the control condition 1 $\mathrm{ml}$ of water without nematodes was added to the leaves. Suspensions were added using a pipette, with the tip being changed after every treatment. The plastic vessels were then closed. 
The plastic vessels were put in a rearing chamber (RK-900 CH type from Kambič Laboratory equipment, Semič, Slovenia) with working capacity of $0,868 \mathrm{~m}^{3}$ (width $\mathrm{x}$ height $\mathrm{x}$ depth $=$ $1000 \times 1400 \times 620 \mathrm{~mm}$ ), and with every treatment in 5 replications. Efficacy was tested at three different temperatures $\left(15,20\right.$, and $\left.25^{\circ} \mathrm{C}\right)$, but with constant light:dark ratio of $4: 20$ and relative humidity of $95 \%$. The number of dead individuals was determined 4 days after treatment.

\subsection{Statistical analysis}

A multifactor analysis of variance (ANOVA) was conducted to determine the differences in mortality rates (\%) between the larvae and adults of banded greenhouse thrips, reared in three different treatments (two species of EPNs and untreaed control) at three different temperatures. Before the analysis, each variable was tested for homogeneity of treatment variances. The mortality rate data were corrected for control mortality according to Abbott's formula (Abbott, 1925) and the data were normalized by an arcsine square-root transformation before the analysis. Duncan's multiple range test $(P \leq 0.05)$ was used to separate mean differences among the parameters in all the treatments. All statistical analyses were performed with Statgraphics Plus for Windows 4.0 (Statistical Graphics Corp., Manugistics, Inc., Maryland, USA) and figures were created with MS Office Excel 2003 (MS Corporation). The data are presented as untransformed means \pm SE.

\section{RESULTS}

With general analysis of variance it was determined that temperature $(\mathrm{P}<0.0498)$ and developmental stage of the pest $(\mathrm{P}<0.0002)$ had significant effects on mortality rate of $H$. femoralis, while no significant effects were seen with nematode species $(\mathrm{P}<$ 0.1337), interaction between EPN species and temperature $(\mathrm{P}<0.3412)$, interaction between EPN species and developmental stage $(\mathrm{P}<0.2202)$, interaction between temperature and developmental stage of the pest $(\mathrm{P}<0.3821)$ and interaction between all three factors $(\mathrm{P}<0.8940)$. With average mortality of $37.68 \pm 4.44 \%$, larvae were more susceptible to nematode attack than were adults, which showed a mortality rate of $15.40 \pm 3.31 \%$. Significantly the lowest mortality of thrips was seen at $20^{\circ} \mathrm{C}(16.88$ $\pm 4.65)$, and between $15(30.89 \pm 6.12 \%)$ and $25^{\circ} \mathrm{C}(31.85 \pm 4.86 \%)$ no respective significant differences were ascertained. $H$. bacteriophora showed the highest efficacy rates against thrips $(30.71 \pm 4.75 \%)$, but this was not significantly higher than the mortality rate caused by $S$. feltiae $(22.37 \pm 3.94)$.

Individual analysis of variance did not confirm any influence of EPN species $(\mathrm{P}<$ 0.1151), temperature $(\mathrm{P}<0.5276)$, or their interaction $(\mathrm{P}<0.5220)$ on the mortality of thrips larvae. Larval mortality ranged from just over $23 \%\left(\mathrm{~S}\right.$. feltiae at $\left.25^{\circ} \mathrm{C}\right)$ to approximately $50 \%$ (H. bacteriophora at 15 and $25^{\circ} \mathrm{C}$ ) (Figure 1).

Temperature had significant influence $(\mathrm{P}<0.0049)$ on adult pest mortality, but no significant effects were found with EPN species $(\mathrm{P}<0.7693)$ and its interaction with temperature $(\mathrm{P}<0.5696)$. The lowest efficacy of both biological agents was found to occur at $15^{\circ} \mathrm{C}$ (about $17 \%$ mortality of adults) and at $20^{\circ} \mathrm{C}$ (about $5 \%$ mortality of adults), beside that between $15^{\circ} \mathrm{C}$ (about $15 \%$ mortality of adults at both nematode species) and $25^{\circ} \mathrm{C}$ (about $30 \%$ mortality of adults treated with $H$. bacteriophora) no significant differences were determined (Figure 2). 


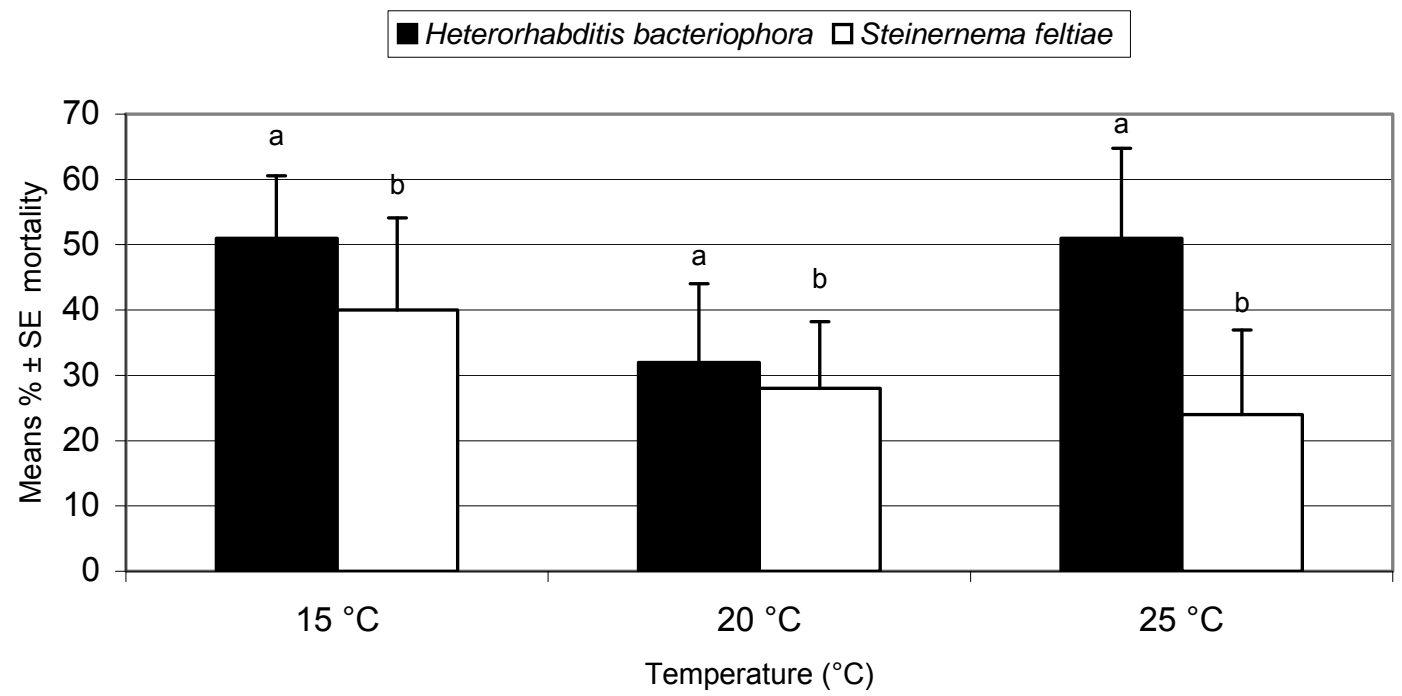

Figure 1: Mean larval mortality $( \pm \mathrm{SE})$ of Hercinothrips femoralis treated with two different species of entomopathogenic nematodes (200 IJs/individual) depending on rearing temperature. Data shown are corrected for control mortality and analyzed by multifactor ANOVA. Mean values followed by the same letter do not differ significantly $(P \leq 0.05)$ according to Duncan's multiple range test. The letters correspond to the grouping of means for temperature, while for EPN species no signifficant diferences were established.

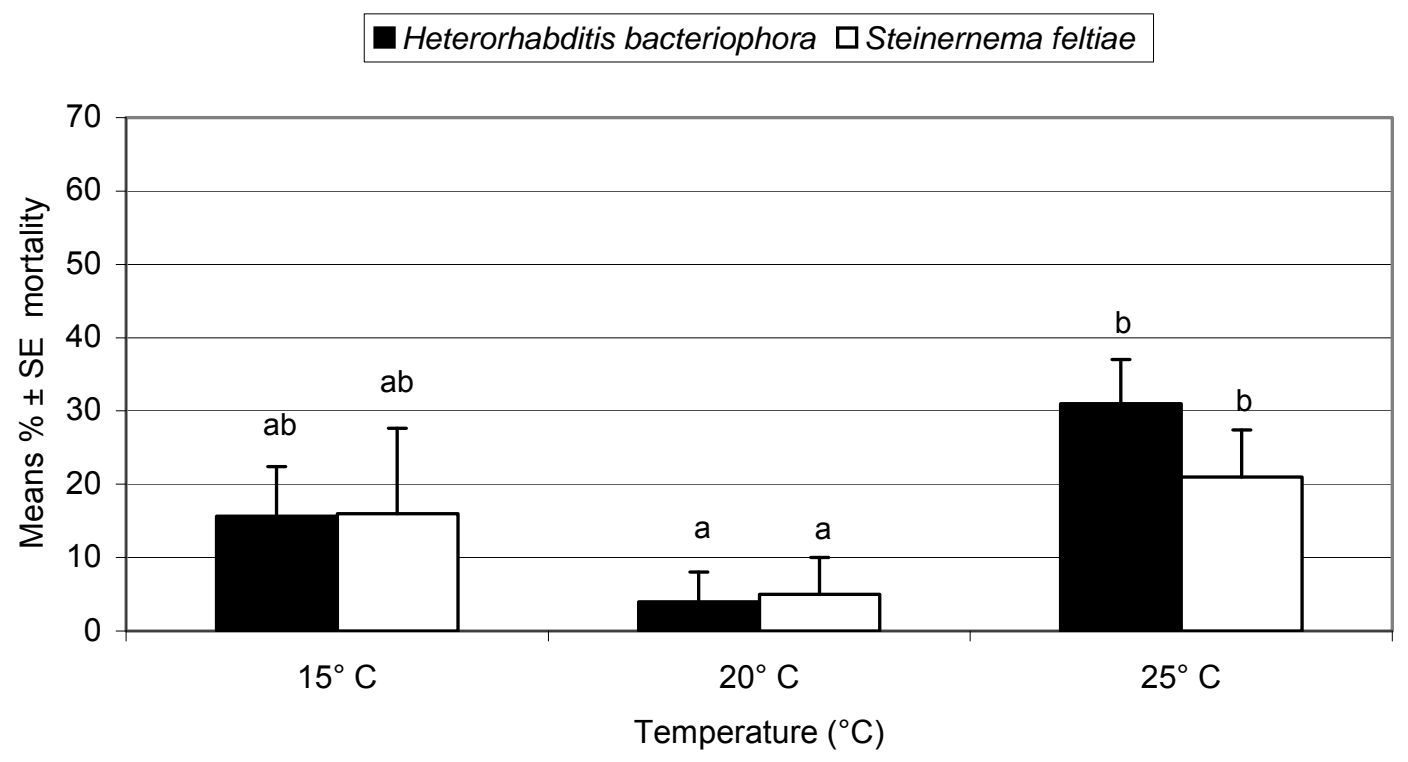

Figure 2: Mean adult mortality $( \pm \mathrm{SE})$ of Hercinothrips femoralis treated with two different species of entomopathogenic nematodes (200 IJs/individual) depending on rearing temperature. Data shown are corrected for control mortality and analyzed by multifactor ANOVA. Mean values followed by the same letter do not differ significantly $(P \leq 0.05)$ according to Duncan's multiple range test. The letters correspond to the grouping of means for temperature, while for EPN species no signifficant diferences were established. 


\section{DISCUSSION}

Though the first record of $H$. femoralis in Slovenia on some of the ornamental plants was expected (Trdan and Vierbergen, 2001), it was somewhat surprising when it was found on young maize plants grown in the laboratory (Trdan, 2002). Some sources (Hercinothrips..., 2002) quoted maize as one of the potential hosts of banded greenhouse thrips. The thrips most likely entered into the laboratory with some ornamental plants, and remained in the same laboratory since 2002 or even earlier.

The fact that indoor work and living places are important habitats of banded greenhouse thrips has implications for the control methods that can be used. Special attention should be paid to guard against secondary damage to human comfort or health. With the choice of some of the environmentally acceptable control methods, we may be able to curcumvent some of the problems associated with chemical pesticides. Among these methods we include EPNs, whose efficacy against Thysanoptera species has been particularly studied with western flowers thrips in the greenhouses. Higher efficacy of EPNs against this pest has been shown with a soil application of the suspension (Buitenhuis and Shipp, 2005), with earlier and multiple applications at lower concentration (Belay et al., 2005), at higher soil moisture (Ebssa et al., 2004a) and temperatures of $25^{\circ} \mathrm{C}$ (Ebssa et al., 2004b).

Foliar applications of EPNs on plants attacked by thrips represents one of the more recent potential methods of their use. Although previous results of such research do not lend strong support to foliar application of EPNs (compared to soil application), particularly due to their sensitivity to desiccation and UV radiation (Shapiro-Ilan et al., 2006), this method could nevertheless be suitable for the control of thrips on (tropical) plants, which often require water applications to leaves and which preferentially grow in places not exposed to direct sunlight. In fact, many hosts of $H$. femoralis like such habitats.

In our research, the larvae of banded greenhouse thrips were more sensitive to nematode infection than were adults. This confirms the known fact that EPNs are most efficient against the larvae and other preimaginal stages of insects, as they can enter their bodies more easily (LeBeck et al. 1993). For this reason, a weaker activity associated with foliar applications $S$. feltiae and $H$. bacteriophora on adults of $H$. femoralis is no surprise. Furthermore, in recent related research on adults of western flower thrips, similar conclusions were reached (Buitenhuis and Shipp, 2005). A poorer efficacy of the nematodes in our research might also be attributed to lower concentration of suspension (200 infective juveniles/individual), which was applied to bean leaves only once. It is often necessary to apply such a suspension repeatedly in order to achieve satisfactory efficacy of these biological agents (Belay et al., 2005), and in this particular detail we see a chance to notably improve the efficacy against $H$. femoralis on ornamental plants via repeated EPN foliar applications.

Temperature had no influence on nematode efficacy against larvae, but this was not the pattern for adults where the mortality was significantly higher at $25^{\circ} \mathrm{C}$. This is in accordance with nematode efficacy in controlling western flower thrips (Ebssa et al., 2004b). We attribute the weak activity of the nematodes against the banded 
greenhouse adults at $20^{\circ} \mathrm{C}$ to the highest vitality of thrips at this temperature, most likely promoting its natural resistance to infection with EPNs.

$H$. femoralis also survives on above-ground parts of host plants during pre-pupal and pupal stages, especially on older leaves (Oetting et al., 1993). Foliar application of the nematodes is therefore a legitimate method of pest control. We note that western flower thrips and many other damaging Thysanoptera species (Tommasini and Maini, 1995) pupate in the soil. Furthermore, thrips in pre-pupal and pupal stages are especially susceptible to EPN infection (Ebssa et al., 2001) and are almost immobile.

Thus these first results concerning the control $H$. femoralis with foliar applications of EPNs showed that these biological agents could be, along with optimal abiotic and biotic factors, an effective enough alternative to the current prevailing (conventional) methods of pest control. Therefore, further research from our group will be oriented to the optimization of foliar application methods of EPNs to control all above-ground developmental stages of the pest.

\section{ACKNOWLEDGEMENT}

This work was supported by the Ministry of Higher Education, Science and Technology and the Ministry of Agriculture, Forestry and Food of the Republic of Slovenia within the programmes L4-6477-0481-04 and Horticulture No P4-00130481.

\section{REFERENCES}

Abbott, W. S. (1925): A method of computing the effectiveness of an insecticide. J. Econ. Entomol., 18: 265-267.

Arthurs, S., Heinz, K. M. (2006): Evaluation of the nematodes Steinernema feltiae and Thripinema nicklewoodi as biological control agents of western flower thrips Frankliniella occidentalis infesting chrysanthemum. Biocontrol Sci. Technol., 16: 141-155

Belay, D., Ebssa, L., Borgemeister, C. (2005): Time and frequency of applications of entomopathogenic nematodes and their persistence for control of western flower thrips Frankliniella occidentalis. Nematology, 7: 611-622.

Beshear, R. J. (1979): Additional records of thrips in Georgia (Thysanoptera: Thripidae). J. Ga. Entomol. Soc., 14, 3: 209-211.

Buitenhuis, R., Shipp, J. L. (2005): Efficacy of entomopathogenic nematode Steinernema feltiae (Rhabditida: Steinernematidae) as influenced by Frankliniella occidentalis (Thysanoptera: Thripidae) developmental stage and host plant stage. J. Econ. Entomol., 98: 1480-1485.

Ebssa, L., Borgemeister, C., Berndt, O., Poehling, H. M. (2001): Efficacy of entomopathogenic nematodes against soil-dwelling life stages of western flower thrips, Frankliniella occidentalis (Thysanoptera: Thripidae). J. Invertebr. Pathol. 78: 119-127. 
Ebssa, L., Borgemeister, C., Poehling, H. M. (2004a): Effects of post-application irrigation and substrate moisture on the efficacy of entomopathogenic nematodes against western flower thrips, Frankliniella occidentalis. Entomol. Exp. Appl., 112: 65-72.

Ebssa, L., Borgemeister, C., Poehling, H. M. (2004b): Effectiveness of different species/strains of entomopathogenic nematodes for control of western flower thrips (Frankliniella occidentalis) at various concentrations, host densities, and temperatures. Biol. Control, 29: 145-154.

Hercinothrips femoralis (O. M. Reuter). (2002): Univ. Hawaii Manoa, Coll. Trop. Agric. Human Resour., http://www.extento.hawaii.edu/kbase/Crop/Type/h_femora.htm (18.02.2002).

Kaya H. K., Gaugler, R. (1993): Entomopathogenic nematodes. Ann. Rev. Entomol., 38: 181206.

Kaya, H. K., Aguillera, M. M., Alumai, A., Choo, H. Y., de la Torre, M., Fodor, A., Ganguly, S., Hazir, S., Lakatos, T., Pye, A., Wilson, M., Yamanaka, S., Yang, H. W., Ehlers, R. U. (2005): Status of entomopathogenic nematodes and their symbiotic bacteria from selected countries or regions of the world. Biol. Control, 38: 134-155.

Kirk, W. D. J., Terry, L. I. (2003): The spread of the western flower thrips Frankliniella occidentalis (Pergande). Agric. For. Entomol., 5: 301-310.

Lacasa, A., Martinez, M. C. (1988): Notas sobre la biografia de Hercinothrips femoralis (Reuter) (Thys: Thripidae), potencial plaga en las plantas ornamentales. Bol. Sanid. Veg. Plagas, 14, 1: 67-75.

Laughlin, R. (1971): A culture method for Hercinothrips femoralis (Reuter) (Thysanoptera). J. Aust. Entomol. Soc., 10: 301-303.

LeBeck L. M., Gaugler, R., Kaya, H. K., Hara, A. H., Johnson, M. W. (1993): Host stage suitability of the leafminer Liriomyza trifolii (Diptera: Agromyzidae) to the entomopathogenic nematode Steinernema carpocapsae (Rhabditida: Steinernematidae). J. Invertebr. Pathol., 62: 58-63.

Lewis, T. (1997): Pest Thrips in Perspective. In: Thrips as crop pests. Lewis T. (Ed.). Wallingford, CAB Int.: 1-13.

Nedstam, B. (2001): Tripsarter i grön innemiljö. Växtskyddsnotiser, 65, 1: 6-9.

Oetting, R. D., Beshear, R. J. (1980): Host selection and control of the banded greenhouse thrips on ornamentals. J. Ga. Entomol. Soc., 15: 475-479.

Oetting, R. D., Beshear, R. J., Liu, T.-X., Braman, S. K., Baker, J. R. (1993): Biology and Identification of Thrips on Greenhouse Ornamentals. Univ. Ga., Res. Bull., No. 414: $20 \mathrm{p}$.

Palmer, J. M., Mound, L. A., de Heaume, G. J. (1989): CIE guides to insects of importance to man. 2. Thysanoptera. CAB Int., Wallingford: $73 \mathrm{p}$.

Pintureau, B., Lassabliere, F., Khatchadourian, C., Daumal, J. (1999): Parasitoides oophages et symbiotes de deux Thrips Europeens. Actes IV Conf. Int. Francoph. d'Entomol., St. Malo, France, 5-9 juillet 1998. Annales de la Société entomologique de France, 35, Supp.: 416-420.

Reiderne, S. K., Jenser, G., Szalay-Marzsó, L. (1997): A Cerataphis orchidearum (Westwood) (Homoptera: Hormaphidae) és a Hercinothrips femoralis (O. M. Reuter) (Thysanoptera: Thripidae) elöfordulása hazai üvegházakban. Növvéd., 33: 239-241.

Scarpelli, F., Bosio, G. (1999): Echinothrips americanus Morgan, nuovo tisanottero delle serre. L'Infor. Agrar., LV, 2: 59-61. 
Shapiro-Ilan, D. I., Gouge, D. H., Piggott, S. J., Fife, J. P. (2006): Application technology and environmental considerations for use of entomopathogenic nematodes in biological control. Biol. Control, 38: 124-133

Simon, S. (1993): Pests of bananas in the French West Indies. Infomusa. 2, 1: 8.

Takrony, M. O. (1973): Bionomics and control of sugar-beet thrips Hercinothrips femoralis (Reuter). Univ. of Reading, PhD Thesis.

Tommasini, M. G., Maini, S. (1995): Frankliniella occidentalis and other thrips harmful to vegetable and ornamental crops in Europe. In: Biological control of thrips pests (eds. van Lenteren et al.), Wageningen Agricultural University Papers, Wageningen, 95-1: 1-42.

Trdan S., Vierbergen G. (2001): The risk of introduction of some economically important thrips species (Thysanoptera) to Slovenia. Lectures and papers presented at the $5^{\text {th }}$ Slovenian Conference on Plant Protection, Čatež ob Savi, 6-8 March 2001. Maček J. (ed.). Ljubljana, Plant Protection Society of Slovenia: 303-311 [Slovenian].

Trdan, S. (2000): A simple method for rearing of thrips (Thysanoptera) in laboratory to study their bionomics. Res. Rep., Biotech. Fac., Univ. Ljubl., 75: 19-25.

Trdan, S. (2002): Hercinothrips femoralis (Reuter) also recorded in Slovenia. Sodob. kmet., 35: 242-244 [Slovenian].

Tusnadi, C. K., Nemstothy, K. K. (1992): A barna uveghazi tripsz (Hercinothrips femoralis O.M. Reuter; Thysanoptera: Thripidae) uj tapnovenyei Magyarorszagon. Növvéd., 28:, 495-499.

Vierbergen G. (1995): International movement, detection and quarantine of Thysanoptera Pests. In: Thrips Biology and Management, The 1993 Int. Conf. Thysanoptera: Towards understanding thrips management, Burlingt., Sep. 28-30 1993. Parker et al. (Eds.). N. Y., Plenum Press: 119-132. 